Ann. Biol. anim. Bioch. Biophys. I966, 6 (4), 479-482.

\title{
ULTRASTRUCTURE DE LA MANCHETTE DE LA SPERMATIDE CHEZ LE BÉLIER ET LE TAUREAU
}

\author{
M. COUROT et J. FLÉCHON \\ avec la collaboration technique de Christiane Ricietin \\ Laboratoire de Physiologie de la Reproduction, \\ Centre de Recherches vétérinaires et zootechniques, 37 - Nouzilly; \\ Laboratoire de Microscopie électronique, \\ Centre national de Recherches zootechniques, 78 -Jouy-en-Josas
}

SOMMAIRE

La manchette est une structure transitoire de la spermatide, constituée de microtubules parallèles au grand axe de la cellule. Elle entoure la partie postérieure du noyau et le début du flagelle, formant une sorte d'enveloppe dans laquelle les microtubules sont reliés entre eux par des ponts, ce qui, en coupe transversale, lui donne l'apparence d'une chaîne.

De nombreux auteurs ont mentionné la présence d'une structure morphologique particulière, la manchette, dans le cytoplasme des spermatides au cours de leur phase d'allongement. Signalée tout d'abord par KöLLIKER (I867, cité par MÈves, I899) et souvent observée ensuite, la manchette est décrite comme une sorte d'enveloppe fibreuse qui entoure la partie postérieure du noyau et le début de la pièce intermédiaire de la spermatide ; elle disparaît avant la fin de la spermiogenèse. Son rôle reste encore inconnu. Les observations effectuées en microscopie électronique ont donné lieu à des interprétations contradictoires : d'après certains auteurs, 1a manchette possède une structure filamenteuse (WATsON, I952 ; BRöKELMANN, I963; GARDNER, I964); pour d'autres, elle est formée de fins tubules (Burgos et Fawcett, I955; Nagano, I962; Bradke, I963; Porter et al., I964).

L'étude de la spermatide du Bélier et du Taureau nous a permis d'effectuer les observations qui suivent. 


\section{MATÉRIEL ET MÉTHODES}

Des fragments de testicules ont été fixés pendant une heure dans une solution à 4 p. Ioo de glutaraldéhyde dans un tampon phosphate à pH 7,25 (SABATINI $e t$ al., ig62) puis pendant le même temps dans une solution d'acide osmique à 2 p. Ioo dans le même tampon au même pH (Millonig, I962). L'inclusion a été effectuée dans l'épon ou dans l'araldite. Les coupes colorées à l'acétate d'uranyle et au citrate de plomb ont été recouvertes d'un film de carbone et observées à l'Elmiscop I Siemens.

\section{RÉSULTATS}

Dans les deux espèces étudiées, la manchette se présente sous l'aspect d'une série de microtubules dont le diamètre extérieur mesure de 250 à $300 \AA$ et la paroi dense $6_{5} \AA$ d'épaisseur (le diamètre est assez constant pour les microtubules d'une même cellule : coefficient de variation inférieur à ro p. Ioo). Presque rectilignes et parallèles entre eux, ils prennent appui comme chez le Chat (BURGos et FAWCETT, 1955), sur un étranglement de la membrane cytoplasmique flanqué d’un dépôt de substance osmiophile. Cette structure située à la limite postérieure de l'acrosome correspond probablement au segment équatorial (pl. I). Ils se développent à peu près parallèlement à l'axe d'allongement de la cellule et se prolongent au-delà du noyau dans le cytoplasme où s'ébauche la pièce intermédiaire du futur spermatozoïde. La manchette entoure l'axonème du flagelle en s'intercalant entre celui-ci et les mitochondries. La disposition relative des microtubules ne semble pas laissée au hasard; la manchette se présente, en effet, comme une gaine dont la paroi d'épaisseur régulière $(0$, I5 $u$ environ) est formée d'un assemblage de faisceaux creux, ou cylindres, composés de microtubules. Ceux-ci forment en coupe transversale des figures polygonales dans lesquelles ils sont reliés entre eux par des " ponts » de même épaisseur que celle de leur paroi (pl. 3).

La manchette est une formation transitoire : elle apparaît lorsque le noyau de la spermatide commence à s'allonger, mais ne subsiste que peu de temps sous sa forme différenciée, I/4 de la durée de la spermiogenèse, soit 4 et 5 jours au plus, respectivement chez le Bélier et le Taureau (Ortavant, I958 ; Hocherfau, i965) : en effet, quand le noyau de la spermatide est complètement allongé, les microtubules ont totalement disparu.

\section{DISCUSSION ET CONCLUSION}

Ia présence de la manchette en tant que structure cytoplasmique différenciée au cours de la spermiogenèse semble générale puisqu'on 1'a signalée dans tous les groupes étudiés au microscope électronique : Insectes (BACCETTI et BAIRATI, I964), Vers (Gatenby et DaLiTON, I959; Bradke, I963), Batraciens (Burgos et FAwCETT, I956), Reptiles (Boisson et MatTei, I965), Oiseaux (Nagano, I962) et Mammifères (WATSON, I952; etc.). 
Les observations que nous rapportons sur l'ultrastructure de la manchette chez le Bélier et le Taureau complètent ce qui a été trouvé dans les autres espèces. L'analyse de notre matériel montre très nettement qu'il s'agit d'une structure formée de microtubules; elle permet de préciser l'arrangement de ces microtubules associés de manière bien définie dans l'espace.

Plusieurs auteurs ont rapporté la présence de microtubules dans différentes sortes de cellules en interphase (BEHNKE, I964; LEDBETTER et PORTER, I963; SANDBORN et al., I964, etc...). Ces structures seraient associées, soit au transport intracellulaire de substance (SLAUTTERBACH, Ig63), soit à des mouvements cytoplasmiques (PORTER et al., I964) ce qui semble être le cas du type de cellule étudié ici. On pourrait donc penser que les microtubules de la manchette représentent une sorte de cytosquelette qui assure une protection mécanique de la spermatide au cours de sa transformation, tout particulièrement au niveau de l'articulation entre la pièce intermédiaire et la tête du futur spermatozoïde. Cependant, nous n'avons pas effectué d'expériences qui pourraient confirmer cette hypothèse.

Il reste, en outre, à préciser l'origine et le devenir de la manchette pour mieux la situer dans le schéma général des mécanismes de la spermiogenèse $\left.{ }^{1}\right)$.

Rę̧u pour publication en juillet $\mathrm{I} 966$.

\section{SUMMARY}

FINE STRUCTURE OF THE MANCHETTE IN THE SPERMATID OF BULL AND RAM

The manchette is a transient structure of the spermatid which can be seen during the elongation phase of the cell nucleus ( 4 and 5 days in the Ram and in the Bull). It consists in a layer of microtubules (diameter 250-300 $\AA$ ) parallel to the long axis of the cell and around the posterior part of the nucleus and the beginning of the flagellum. Microbutules are related so that, in cross section, manchette looks like a chain.

\section{RÉFÉRENCES BIBLIOGRAPHIQUES}

ANDRÉ J., Ig̣63. Some aspects of specialization in sperm, in : MAzia D., TyLER A., general physiology of cell specialization, 9I-II5, Mc GRAw-HiLl 3ook Co, New York.

BACCETII B., BaIRATI A., 1964. Indagini comparative sull'ultrastruttura delle cellule germinali maschili in Dacus Oleae GMeL., ed in Drosophila melanogaster MEIG. Redia, 49, I-29.

BEnNke O., I964. A preliminary report on microtubules in undifferentiated and differentiated vertebrate cells. J. Ultrastruct. Res., 11, I 39-146.

Boisson C., Mattei X., I 965 . Sur la spermiogenése de Python sebae (GMelin) étudié au microscope électronique. C. R. Soc. Biol., 159, I I92-1 194 .

Bradke D. L., I963. The origin and development of the manchette during spermatogenesis. Anat. Rec., 145, 2 I0.

BRöKELMANN J., I963. Fine structure of germ cells and Sertoli cells during the cycle of the seminiferous epithelium in the Rat. Z. Zellforsch., 59, 820-850.

Burgos M. H., Fawcett D. W., I 955. Studies on the fine structure of the mammalian testis. I. Differentiation of the spermatids in the Cat (Felis domestica). J. biophys. biochem. Cylol., 1, $287-300$.

Burgos M. H., FAwCETT D. W., 1956. An electron microscope study of spermatid differentiation in the toad, Bufo arenarum HeNsEL. J. biophys. biochem. Cytol., 2, 223-240.

(1) Signalons qu'AndRÉ ( 1963 ) a observé un stade final de la manchette chez le lapin : microtubules en relation avec la structure membranaire décrite, mais courts et orientés dans tous les sens. 
GaRdner P. J., I964. Fine structure of the seminiferous tubule of the swiss mouse. Univ. Nebraska, Ph. D. Thesis.

Gatenby J. 13., Dalton A. J., 1959. Spermiogenesis in Lumbricus herculeus. An electron microscope study. J. biophys. biochem. Cytol., 6, 45-52.

HocirereaU M. T., ig65. Communication personnelle.

I.edbetter M. C., Porter K. R., ig63. A "Microtubule " in plant cell. Fine structure. J. Cell. Biol., 19, $239-250$.

Meves F., I899. Über Struktur und Histogenese der Samenfäden des Meerschweinschens. Arch. Mikr. Anat., 54, 329-402.

Millonig G., I962. Further observations on a phosphate buffer for osmium solutions; in BreEsE S. J,

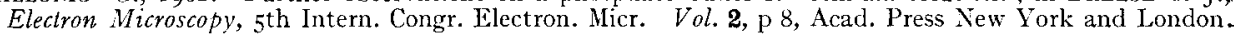

NAGano T., I962. Observations on the fine structure of the developing spermatid in the domestic chicken. J. Cell Biol., 14, 193-206.

Ortavant R., I958. Le Cycle spematogénétique chez le Bélier. Thèse Doct. Sci., Paris, I 27 pp. Ed. I959. Ann. Zootech., 8, $183^{-244}$ et $27 \mathrm{I}-322$.

Porter K. R., Ledbetter M. C., Badenilausen S., 1964. The microtubule in cell fine structure as. a constant accompaniment of cytoplasmic movements; in Electron Microscopy, Proc. 3rd Europ. Reg. Conf., Prague, Vol. $B$, i i $9^{-1} 20$.

Sabatini D. D., Bensch K. G., Barrnett R. J., Ig62. New fixatives for cytological and cytochemical studies; in Breese S. J., Electron Microscopy, $5^{\text {th }}$ Intern. Cong. Electron. Micr., Vol. 2, L3. Acad. Press. New York and London.

Sandborn F., Koen P. F., McNabb J. D., Moore G., i964. Cytoplasinic microtubules in mammalian cells. J. Ultrastruct. Res., 11, I23-1 38 .

Slauterback D. B., 1963. Cytoplasmic microtubules. I. Hydra. J. Cell. Biol., 18, 367-388.

Watson M. L., 1952. Spermatogenesis in the albino rat as revealed by electron microscopy. Biochim. biophys. Acta. 8, 369-374.

\section{PLANCHE I}

Spermatite de Taureau en coupe longitudinale ( $\times 43200)$.

$\mathrm{A}=$ acrosome.

$\mathrm{Ma}=$ manchette.

$\mathrm{N}=$ noyau.

$\mathrm{E}$ = étranglement de la membrane cytoplasmique souligné d'un dépôt de matière dense où semblent s'insérer les microtobules. 


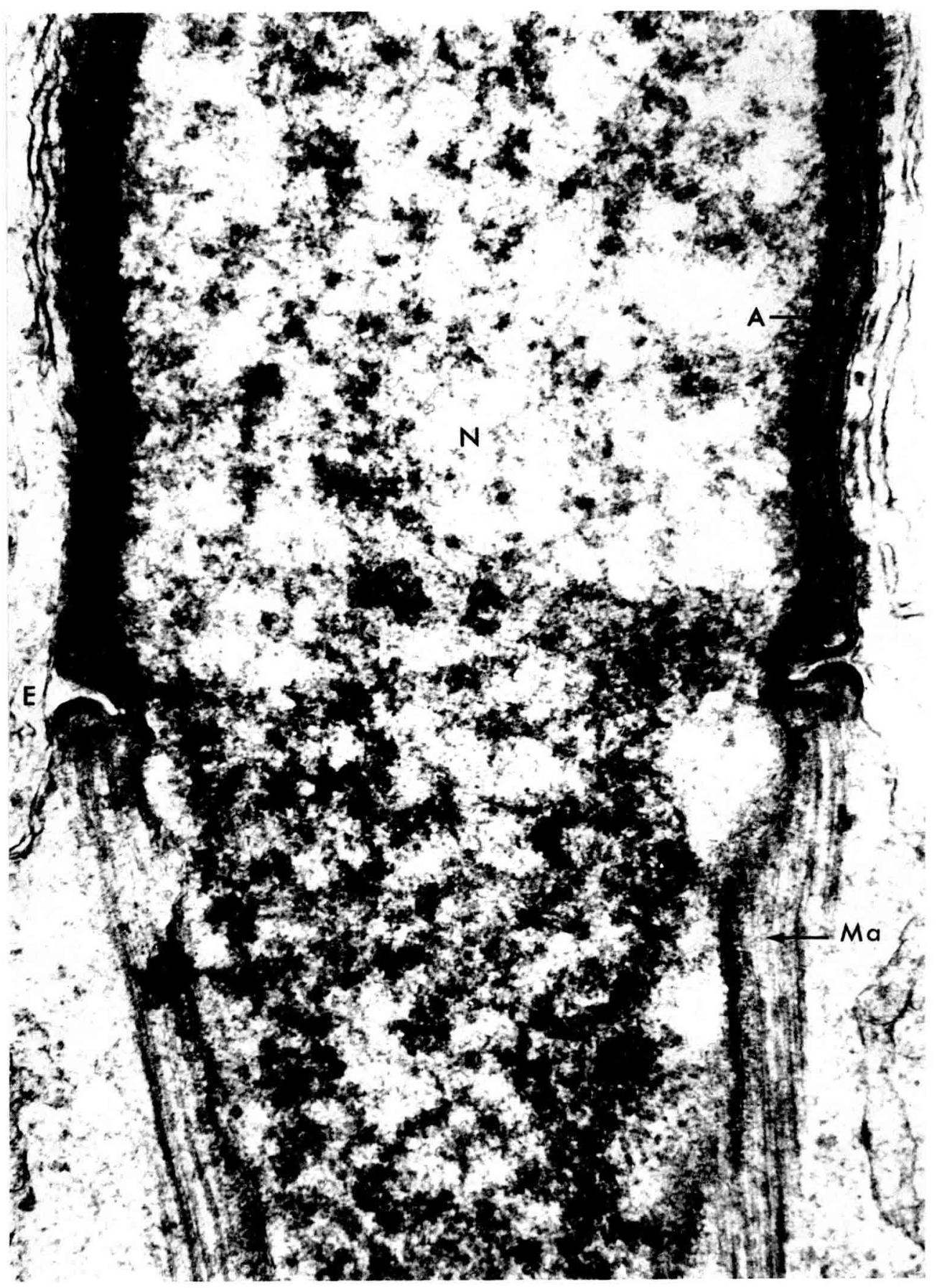




\section{PLANCHE II}

Spermatide de Taureau en coupe transversale. (Plan de coupe postérieur au noyau). $F=$ Filaments axiaux du flagelle; $\mathrm{Ma}=$ Manchette $; \mathrm{Mi}=$ Mitochondrie. $\times 44200$. 
Ann. Biol. anim. Bioch. Biophys., 1966, 6 (4).

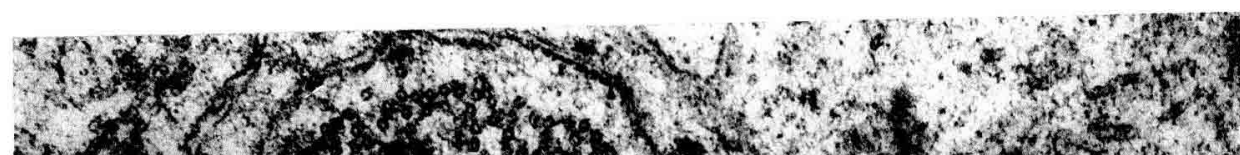

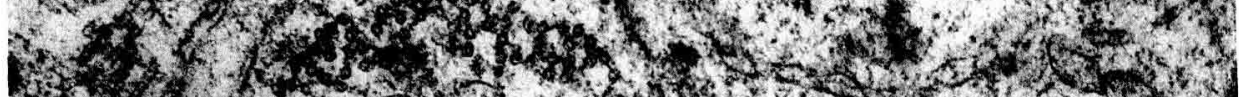

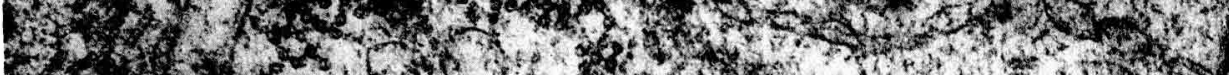

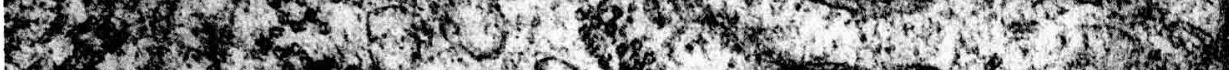

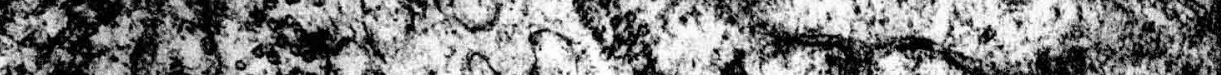

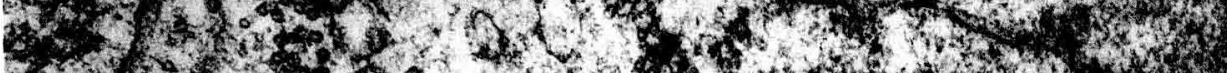

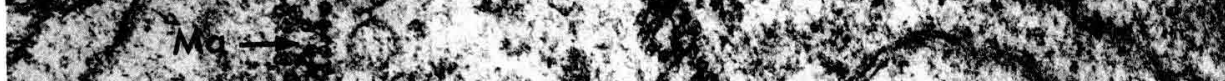

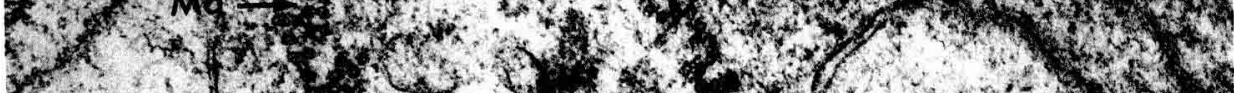

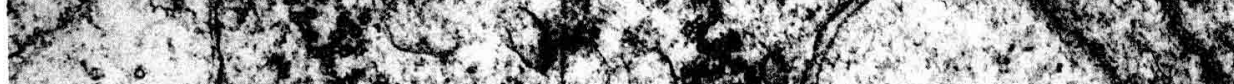
S- 0 .

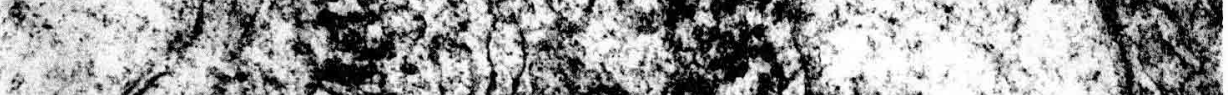

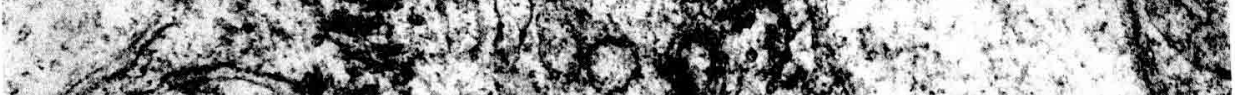
300 .

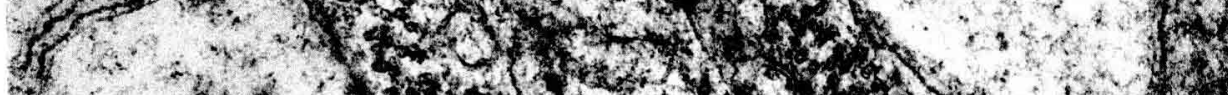

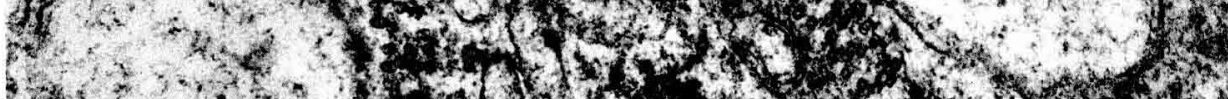

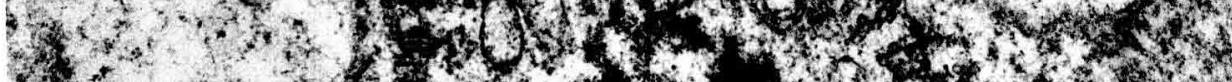

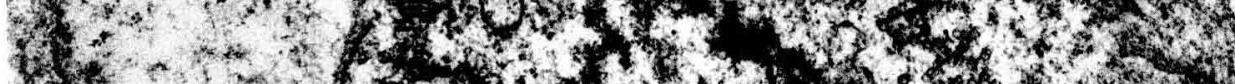

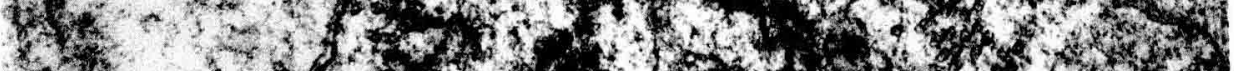

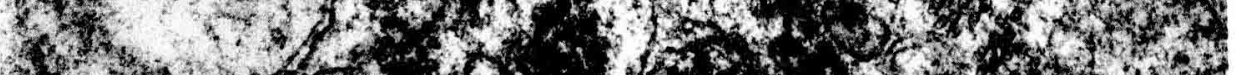

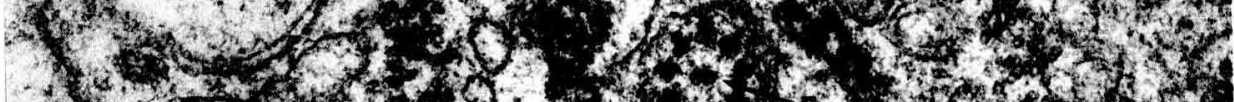

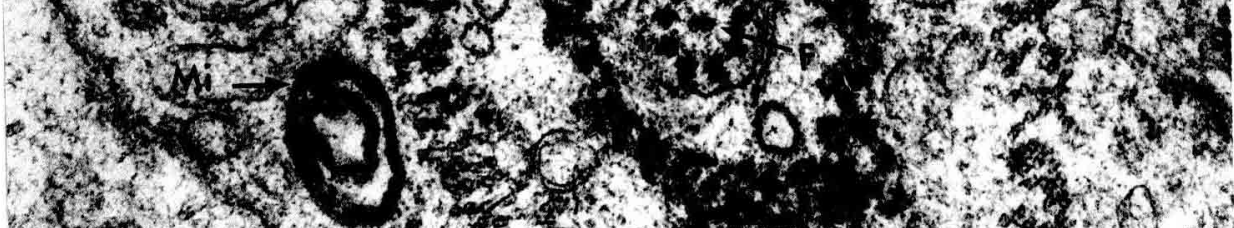

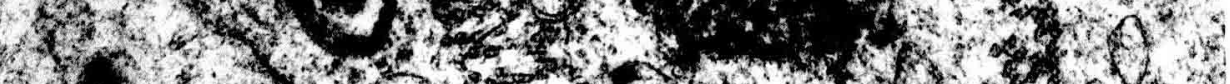

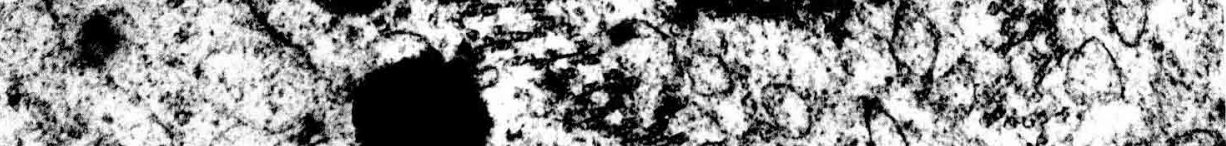

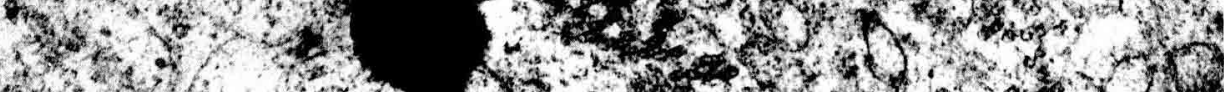

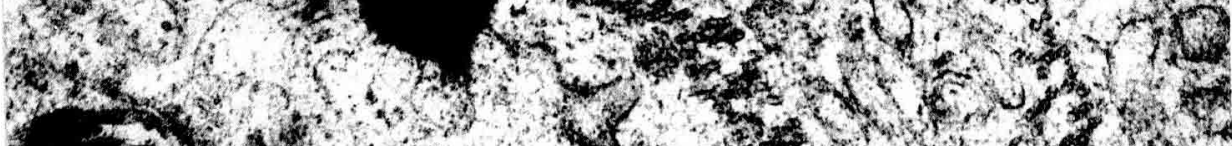

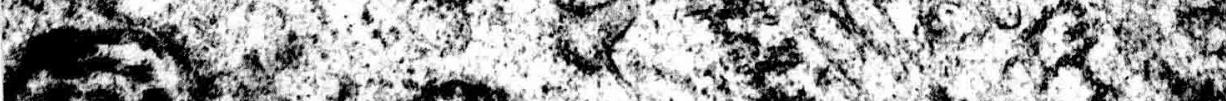

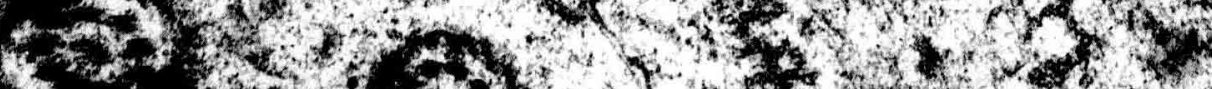

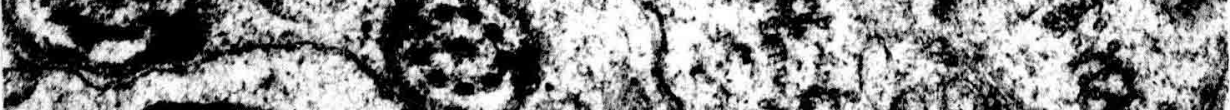

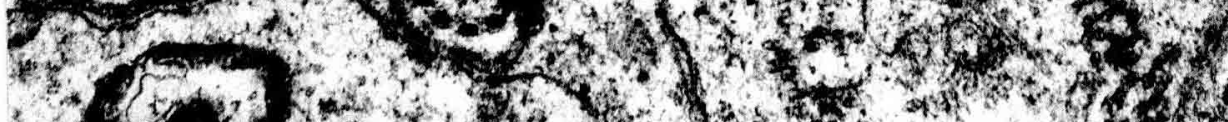

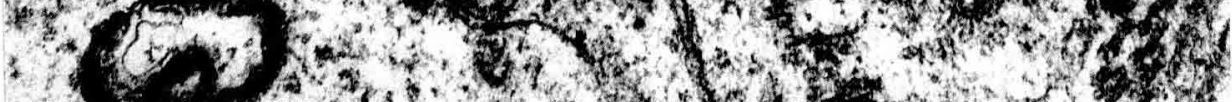

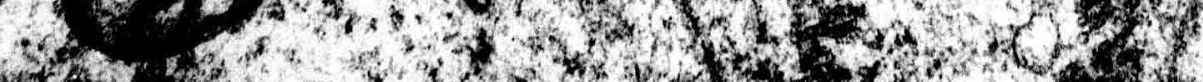

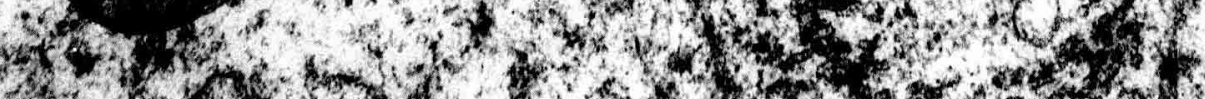

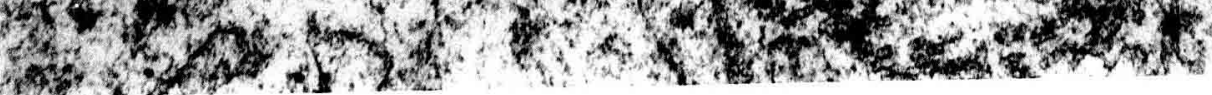

\section{COUROT, J. FLECHON}




\section{PLANCHE III}

Détail d'une coupe transversale de manchette montrant les ponts qui relient les microtubules (flèches) $\times 160000$. 


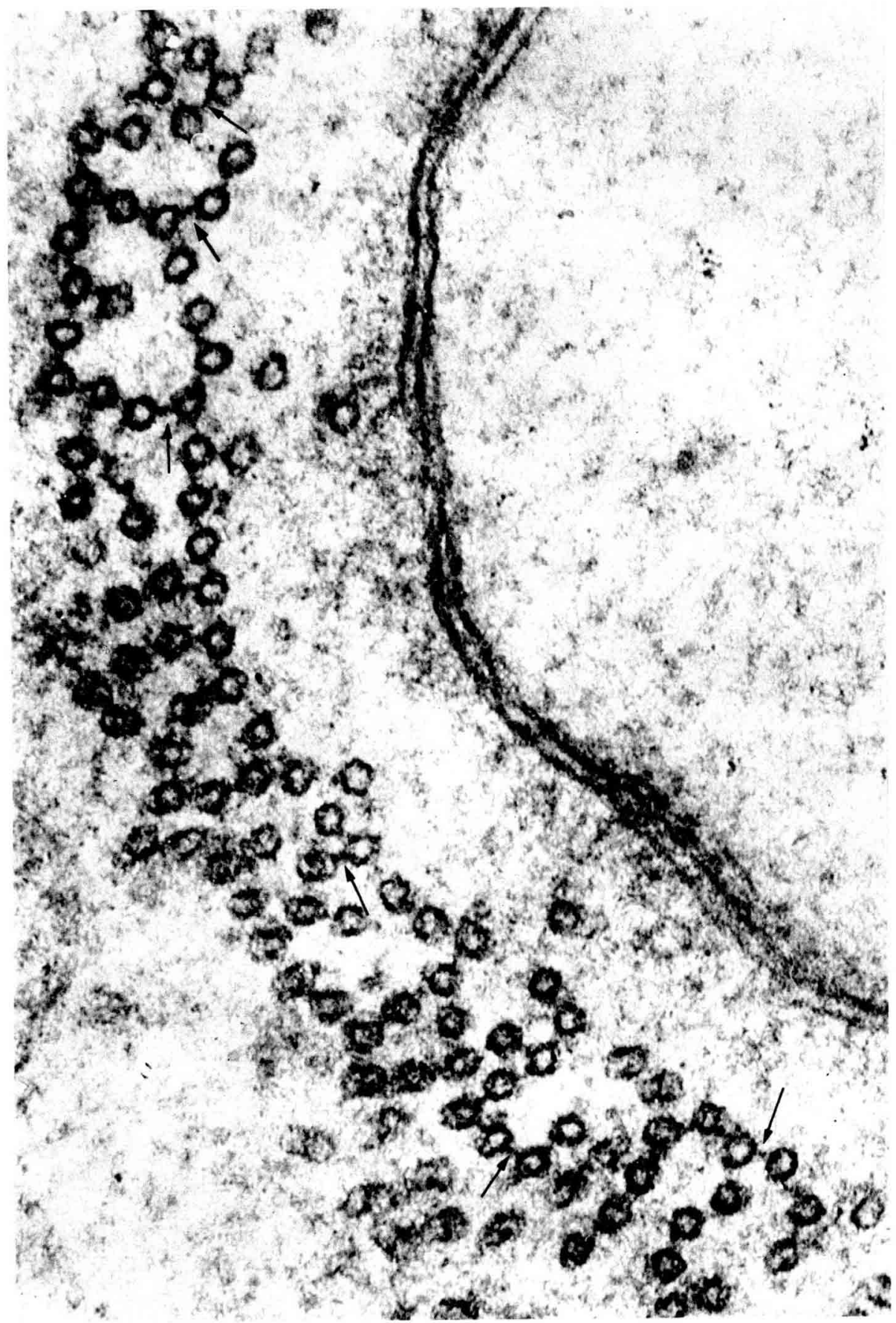

